\title{
REVITALIZATION OF AREAS IN THE METROPOLIS - AN URBAN FARM AS AN EXAMPLE OF INTEGRATION OF GREENERY AND BUILDINGS IN THE URBAN LANDSCAPE
}

\author{
Magdalena Grochulska-Salak ${ }^{\bowtie}$, Kinga Zinowiec-Cieplik ${ }^{\bowtie}$ \\ Faculty of Architecture, Warsaw University of Technology, Warsaw
}

\begin{abstract}
Modern cities introduce revitalization programs that enable more rational and sustainable use of ecosystem resources. The revitalization activities in modern metropolises, understood as the process of making grow and develop, linked to implementing of novel technological solutions integrating buildings with nature as a significant building development equipment and public space areas have been analysed. The research was focused on the analysis of designs and implementations of city urban farms, which serve as modern examples of investments with social functions, namely public utility and plants production or farming for nutritional needs for the local community. The study presents the research on interdisciplinary discussion regarding the issues of urban regeneration by the implementation of urban farms in the modern 21 st century metropolis. Treating buildings as a biotope could increase the biologically active area. Looking for the possibility of introducing and increasing agricultural production in the modern metropolis, it turns out that the roofs and elevations have a lot of potential. The article presents the analysis of diversity of crops for the last 20 years on architectural surfaces in order to show the possibility of using them as an important element of city revitalization.
\end{abstract}

Key words: revitalization, metropolis, land regeneration, urban agriculture, urban farms, greenery integrated with buildings

\section{INTRODUCTION}

This study describes the research problem of land regeneration in the metropolis. It is pointed out there in that revitalization should be redefined in relation to the question of integration between greenery and development in the urban landscape.

The aim of the research was to prove that the basic condition for the revitalisation of the metropolis is the introduction of new social, environmental and ecosystem services by the implementation of biologically active areas and the implementation of modern and innovative technologies for green and blue infrastructure.
Research hypothesis: "The urban farm could provide an element of the metropolitan revitalization program, as well as a component of the integration of greenery and buildings in the urban landscape".

The proof is conducted through the analysis of two debated topics: (i) the implementation of biologically active areas within intensive development by building of integration with greenery; (ii) an urban farm as a part of the revitalization program - new metropolitan functions.

Research main method was multi-criteria comparative qualitative analysis conducted in relation to literature, revitalization programs, legislative and planning 
provisions chosen cities. The article describes research conclusions and presents the representative examples contained in the analytical material. The formulated urban farms' typology comprises a summary of studies on urban crops and biomass for the needs of ecoproduction in the city.

There exists a need for intervention or re-urbanization that concerns sustainable transformation the land use and altering building developments for post-industrial areas, undeveloped "field reserves".

In Poland, the Act on revitalization of 9 October 2015 provides guidelines for the implementation of programs. To formulate actions for optimal development with the use of local potential is seen as the basis for any revitalization program. The analysis of the programs indicates the need to conduct research to redefine revitalization for the metropolis development including the urban farm implementation in the urban structure.

Being a multi-criteria issue, revitalisation concerns urban, architectural, socio-economic and natural formation. The "restoration of life", understood as actions for the social economy, improvement of the natural system of the city, introduction of ecosystem services, provides the essential goal for revitalisation. The phenomenon of revitalization concerns also to adding new content and values by taking actions in order to improve the functional and spatial structure of the city. The new "content", as shows the article, refers to the design that takes into account biodiversity in the natural system, the coexistence of humans in the urban environment and the formation of biologically active areas integrated with urban building development.

\section{INTEGRATION OF BUILDINGS WITH GREENERY - IMPLEMENTATION OF BIOLOGICALLY ACTIVE AREAS IN INTENSIVE URBAN DEVELOPMENT}

The implementation of biologically active areas in the city is one of the indicators of urban planning studies. The analysis of spatial development issues, as well as publications and investments that implement modern models of biologically active areas, postulate the necessity to define a multi-criterion biologically active surface. In order to do so, urban planners usually use surface coefficients (percentage share of area development), rather than qualitative coefficients (green efficiency, functionality, ecosystem services, bio-production). The analysis of the subject and the strategy for the development of cities implementing the sustainability ideas, indicates the need to introduce green infrastructure in the city, as biologically active areas, for the sake of execution of various ecosystem tasks. Especially ecosystem services, which give us tangible benefits (Szczepanowska, 2007; Kronenberg, 2016) to be able to satisfy the people needs must be in good condition (MEA, 2005). In the city, getting a good environmental status can be achieved by creating a green infrastructure network. Research shows that green infrastructure condition depends on the biologically active area (Szulczewska et al., 2014). The greenery and water in the city may be employed to fulfil numerous tasks in order to shape the urban environment. Properly implemented retention reservoirs (rain gardens) equipped with vegetation can regulate the temperature, humidity and air quality by means of processes of evapotranspiration, filtration and absorption of impurities. The greenery in the city serves also the provisioning services: the oxygen provide by photosynthesis' process, the food supply and the biomass production to produce energy by biofuels. Arguments supporting the implementation of green infrastructure integrated with buildings include also: building insulation (lower heating and cooling costs), increasing biodiversity, limiting the urban heat island phenomenon, limiting excessive noise, retention and management of rainwater (water retention and its reuse). It is estimated that an extensive roofs can retain about $60 \%$ of rain per year (Kwiecińska \& Szałata, 2013).

Contemporary spatial planning should account for parameters such as functional and quality, as well as greenery efficiency, thereby optimizing the way of city development. Revitalization works also as a method of protecting cultural property (Derejski, Kubera, Lisiecki \& Macyra, 2012). Revitalization also aims at social integration and creating awareness of the place, identifying with the place. These objectives are fostered by the implementation of greenery interconnected with the building. The analysed examples in $21 \mathrm{st}$ century metropolises are commonly related with the introduction of greenery on and into buildings. This issue is a new one in urban, architectural, technologi- 
Grochulska-Salak, M., Zinowiec-Cieplik, K. (2019). Revitalization of areas in the metropolis - an urban farm as an example of integration of greenery and buildings in the urban landscape. Acta Sci. Pol. Architectura, 18 (3), 15-24. doi: 10.22630/ASPA.2019.18.3.31

cal and economic terms in a deeper sense of sustainability considering contemporary threats (including climate changes, etc.). The key to solving the problem of lack of biologically active surfaces, in intense urban development could be plants' introduction to roofs and on façades. Green roofs may be implemented in an extensive and intensive type form, or as mixed systems called semi-intensive. The extensive green roof is covered with stonecrop mats. Light substrates and light vegetation forms are used, while the roof inclination slope can reach up to $25^{\circ}$. The intense and semiintensive green roofs are heavier and more biodiverse. Trees, shrubs, perennials could be cultivate, alleys may be arranged or benches can be installed. Thus, this type of green roofs resemble a square or a small city park. It is used with a maximum inclination of up to $5^{\circ}$ (Köhler, 2010).

Green roofs are usually created on public buildings, such as libraries, town halls, shopping centres, parking lots, and banks, office. Roof gardens are supposed to become an answer to the intense development and to provide a solution to the growing environmental problems in the city (Tokarska \& Osyczka, 2011). The implementation of green roofs as a systemic solution is one of the models for the introduction of green infrastructure into the city. The contemporary metropolis introduce programs and systems of economic incentives, such as tax exemptions and a subsidising system to encourage investors to integrate greenery with architecture. Chicago was the first city in North America to introduce the green roof subsidising program. Its implementation and the subsidising system are conducted by the Chicago Department of Construction (it approves projects and grant applications). Materials promoting and describing investments, namely A Guide to Rooftop Gardening. From the City of Chicago are published by Chicago Department of Environment (City of Chicago, 2001). Green Roofs act for New York City has started since 2018 in order to solve the problem of i.a. reduction stormwater runoff, mitigation the urban heat island effect, biodiversity preservation through green infrastructure on roofs (New York City Council, 2018).

In 2009, Toronto has began to cooperate with the Green Roofs for Healthy Cities - North America Inc. and to work on legal regulations on green roofs management and construction (City of Toronto, 2017). The bill requires developers to cover each new building with at least $50 \%$ of greenery. In France, in March 2016, a legislation was passed introduce the principles of covering roofs of newly constructed commercial real estate's with greenery or solar panels (Article 86 of Law No 2016-1087 on the Recovery of Biodiversity, Nature and Landscapes of 8 August 2016).

In Poland no state regulations exist that would foster the process of green roofs emergence (Kowalczyk, 2011). Wrocław is a Polish city where solutions for city development are introduced in line with the green city concept. In 2015, the City Council passed the resolution for useable floor areas in residential building, exempting from tax if they have installed green roofs or vertical gardens on their external walls with area no smaller than $15 \mathrm{~m}^{2}$ are, during the validity of the resolution. The green garden on the roof must be multi-layered, the plants should be perennial, while the vegetation should amount to no less than $40 \mathrm{~cm}$. These are guidelines for intensive system. As a result of the resolution, the usable areas employed for running a business are not subject to tax exemption. This is one of the elements of Wroclaw's urban policy for introducing an intensive green infrastructure in new investments and in the city and revitalization buildings or part of the city. The extensive green roofs take the form of point investments rather than systemic solutions. Those initiatives are often dictated by the intensity of building development and land shaping, the need to balance the green area to maintain the required percentage of biologically active areas and the considerations arising from the certification of the building accepted by the investor.

The only systemic solution commissioning investments with green infrastructure in Poland are certification programs like EU Green Building, English BREEAM or American LEED. Among the most known biodiversity, intensive Polish green roofs, on which a number of publications have been written, the garden of the University of Warsaw Library can be mentioned (Tokarska \& Osyczka, 2011). The realization of this library building with a green roof and a tunnel along the Vistula and the Copernicus Science Centre building, also with a green roof, made it possible to revitalize the Powiśle district in Warsaw. 
These investments initiated the revitalization of the boulevards and the actual "bringing back to life" of this part of Warsaw, both for people and for fauna and flora, as well as for the improvement of the ecosystem. The Wrocław Sky Tower building is another often described example (Kwiecińska \& Szałata, 2012).

At the turn of the 21 st century, Chicago began to introduce activities aimed at the intense development towards "the green concept" in the spirit of the Latin maxim Urbs in Horto (City in the Garden). In 2000-2001, an intensive ecological garden was created on the roof of the town hall. It was designed by William McDonough, the pioneer and a great advocate of pro-environmental architectural solutions. The aim the investment served was to research the efficiency of such a garden in the aspect of minimizing the effects of the heat island, as well as in light of increasing the biodiversity resources. On an area of $1,886 \mathrm{~m}^{2}$ of the roof, 20,000 species of herbaceous plants has been planted on a 40-centimeter substrate layer. Moreover, the garden includes 100 species of shrubs, 40 species and varieties of climbers and two species and varieties of small hawthorn trees and a local species of apple tree. Over time, several beehives were placed on the roof. Apart from its research function, the garden gained a new utility aspect. The presented examples from Chicago, however, are devoid of a clear production function.

The sustainable goals set by the city authorities of Chicago permitted to create one of the biggest roof garden (9.9 ha) in the world - Millennium Park in the center of the city. These area may be provided as an example of a "green revitalization" model with the use of plants on the roof. Opened in 2004, the public park located between the lake and the central business part of Chicago was built over the railway area once the city obtained air rights concerning the infrastructure. The park fulfils all the functions of greenery in the city, both environmental and socio-cultural ones. Underneath the park there are two multi-level car parks for 4,000 cars and a railway station. On its edge (at Randolph Street), in the close vicinity and program connection to the Pritzker Pavilion located on rooftop, the Harris Theater for Music and Dance was constructed, which is largely underground due to height-related restrictions (Kazmierczak \& Carter, 2010).
Millennium Park serves as an example of greenery on the roof, as well as of plants' integration with buildings and with small architecture and landscaping structure. The functional program of the park enables social integration and execution of ecosystem services.

Another example of revitalization with the implementation of a green roof that serves urban crop farm function is the Brooklyn Grange Farm in New York City located in the Queens district (Fig. 1; Kwiecińska \& Szałata, 2012). The revitalization of the building, with the use of energy-efficient solutions, was prepared by the Bromley Caldari Architects in cooperation with Acumen Capital Partners and Brooklyn Grange LLC. The investment was awarded by the Queens Chamber of Commerce and by the US Green Building Council NYC. Useable crop have been grown on the seven-storey building rooftop from 1917. The farm, of almost $4,000 \mathrm{~m}^{2}$, uses $454 \mathrm{t}$ of growing medium introduced onto the roof - near 40 varieties of vegetables, fruits and herbs are grown on the building (Gnich, 2015). The farm ensures the preservation of biodiversity through solutions such as the use of bee apiaries. The products are sold at urban trade fairs and at 12 nearby restaurant facilities. The place has become a tourist and an educational object, it hosts workshops for primary school children. The farm received a subsidy from the NYC Department of Environmental Protection. The grant is used for the garden extension. Moreover, it is supposed be allocated for the construction of a similar garden on the roof of a building located in the Brooklyn Navy Yard harbour area. In the latter case, the costs of the entire investment was covered by the city fund (Hulicka, 2013). The edible plants are cultivated on a substrate prepared by a cooperative of mushroom growers in Chester County, Pennsylvania (Cole Plakias, 2016).

In Poland, research is also being conducted concerning the technology and possibilities of setting up green roofs along with the analysis of the Wrockaw projects (Szajda-Birnfeld, Pływaczyk \& Skarżyński, 2013). Green roofs can work as an element of urban area sustainable development and provide the subject for research. Among the examples of a green wall installed in Poland, a vertical garden on the façade and inside a pre-war building belonging to the Foundation for Polish Science in Warsaw at Krasickiego Street 
Grochulska-Salak, M., Zinowiec-Cieplik, K. (2019). Revitalization of areas in the metropolis - an urban farm as an example of integration of greenery and buildings in the urban landscape. Acta Sci. Pol. Architectura, 18 (3), 15-24. doi: 10.22630/ASPA.2019.18.3.31

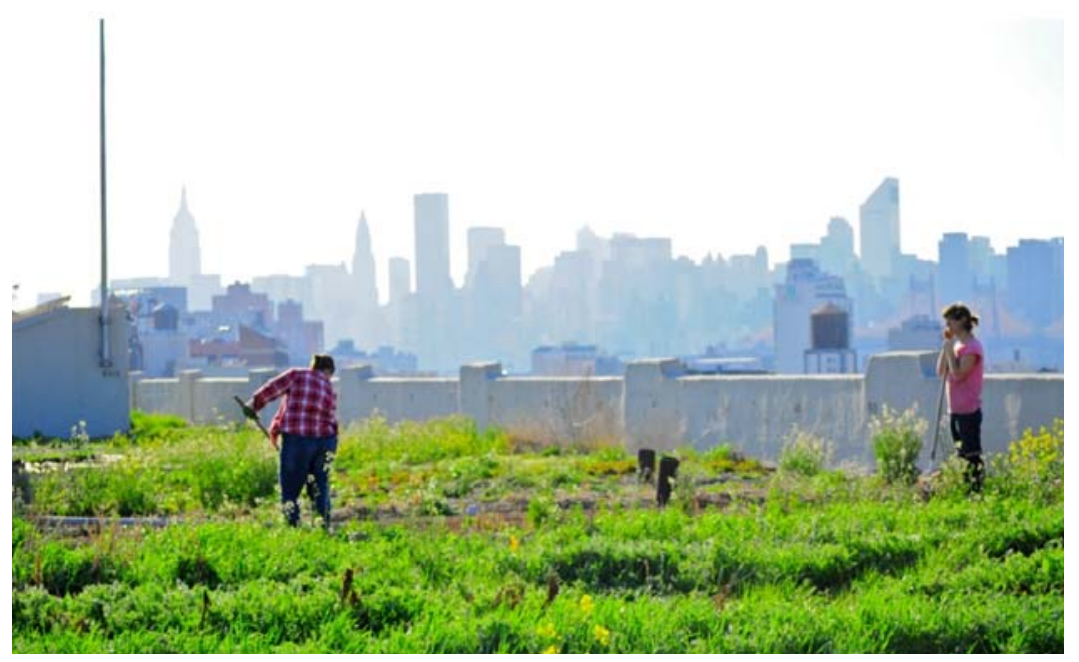

Fig. 1. Urban farm on the roof of Brooklyn Grange (CBrooklyn Grange, source https://www.brooklyngrangefarm.com, accessed 05.09.2018)

can be mentioned. The renovation (revitalization) of the building was performed with the application of principles for ecological and intelligent construction. The FAAB Architektura Białobrzeski/Figurski studio authored the project. In the building numerous recycled materials were applied. Rainwater (the so-called grey water) collection and recovery system was introduced. Heat pumps were used for heating the building. The green front wall was implemented using the technology developed by Sempergreen ${ }^{\circledR}$ Vertical Systems. On about the $260 \mathrm{~m}^{2}$ of the façade space, 17,000 of 20 species were planted, including perennials shrubs and climbing plants (Fig. 2). The plants are placed in containers with substrate and irrigated using

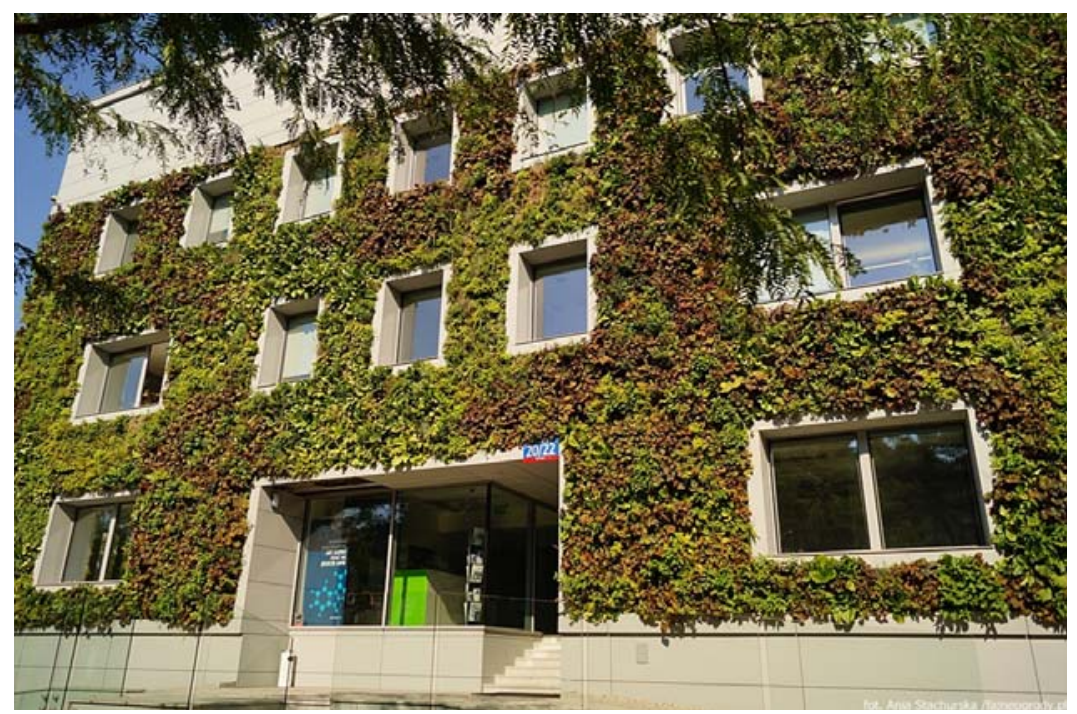

Fig. 2. Green wall on Foundation for Polish Science building in Warsaw (source: https://www.fajneogrody.pl/2015/08/ zielona-sciana-mokotowie.html, accessed 05.09.2018) 
a special computer-controlled system, which consists of a special geotextile that forms a "substrate". The green elevation functions as insulation and improves the microclimate of the building. An extensive green roof over the garage entrance, a garden, a green terrace and turf-covered stairs were also installed in the building.

The example of Polish technology using in revitalisation investments it is the Polish Green Wall developed by the AB System studio, with the co-operation of scientists from the Warsaw University of Life Sciences - SGGW. This technology differs from other technologies of a similar type by the use of substrate medium for growing plants, which embrace mainly shrubs with a small addition of herbaceous plants and vines. The system benefits from its high resistance to climatic conditions in Poland, especially in the eastern regions of the country. This resistance, however, comes at the price of the installation weight, which fluctuates within the limits of from 2.5 to $5.4 \mathrm{kN} \cdot \mathrm{m}^{-2}$. This significant heaviness results in large and strong construction systems. A vertical garden of this type may come in an intensive and extensive version, just as it happens in case of green roofs. In Warsaw, Polish Green Wall was implemented as an independent cubes in front of the Zodiak Warsaw Pavilion of Architecture and the Nowa Rotunda PKO building in the city centre, where gardens serve as an integral part of the public space under renovation. The described Polish technologies offer an alternative to green walls that assume the creepers supported on a frame fixed to the façade.

\section{AN URBAN FARM AS PART OF THE REVITALIZATION PROGRAM - NEW FUNCTIONS OF THE METROPOLIS}

Sustainable revitalization takes account of spatial, functional and social transformations, as well as of issues concerning environmental process management (Białecka, 2014). The revitalization of SEFC postindustrial areas Southeast False Creek in Vancouver (later Olympic Village during the 2010 Winter Olympics) may be seen as a model example of "green revitalisation" which observes the aspect of edible plant cultivation.
While defining the functional-spatial structure and the revitalization program norms, the following assumptions of sustainable development were adopted: opening buildings for greenery, as well as restoration and preservation of eco-habitats; reduction of drinking water consumption; limiting the consumption of thermal and cooling energy; use of recycled building materials; easy adaptation of buildings to new functions; improving the quality of social life (concept of a residential building that promotes mutual social contacts); limitation of car use (it was assumed that places of work, services and leisure will be located within a 10-minute walk from the residential building). Green roofs for growing plants, such as vegetables and flowers were used.

In Canada, the green roofs concept is developed and promoted by local authorities. The use of green roofs for cultivation and garden plots to be used by residents came as a novelty. All terraces, balconies, roofs, courtyards were designed as gardens and as meeting places full of greenery. "The solutions used in the Olympic Village in Vancouver perfectly reflect the nature of revitalization in accordance with the idea of sustainable development. The concept is more closely related to 'green cities' movement" (Bać, 2012).

In the process of revitalisation degraded metropolitan areas, a new program is being formulated, together with a functional-spatial structure, environmental parameters and elements of the urban landscape, as well as a social structure and new economic conditions.

Green and blue infrastructure in the contemporary metropolis become important functional elements of the city equipment that is shaped in accordance with the contemporary concepts of sustainable development. Biologically active areas (greenery, biomass, water) fulfil tasks assigned to three categories: composition and aesthetics, production for the local community and determinants of shaping environments, microclimate and natural system. The implementation of greenery serves also the purpose of integrating the local community. An analysis of modern city green infrastructure potential indicates the function of regulating the parameters of the living environment, temperature, humidity, ventilation, biodiversity and ecosystem efficiency. The tasks mentioned above currently comprise these days also the function of biomass production for 
energy purposes and food production in urban farms. Plant cultivation in the city may be implemented on green roofs or as vertical gardens on building façades or inside multi-functional public buildings.

The cultivation of edible plants for nutritional supply and for the acquisition of biomass, as well as biologically active areas integrated with the buildings, serves social and public utilities functions and plants production or farming for the benefit of local community (Specht et al., 2013).

Research is being conducted into urban farms and into the implementation of buildings integrated with urban greenery. The study indicates the coexistence of buildings and green infrastructure and the integration of the two. The analysis concerned the implementation and design of green roofs, walls and farms in the USA, Asia and Europe. The analytical material was divided into comparative groups, which in effect created the basis for typology. As a result, the typology of urban farms - plant cultivation in the city was formulated.

The first typology type concerns the cultivation of plants grown in the open ground or on the roofs and walls of buildings. These cultivation fields are not protected against environmental contamination and weather conditions. The crops on the revitalized Brooklyn Grange rooftop is the example of this approach

Another category of plant cultivation is represented by the semi-automated production of plants inside buildings. Vegetation is grown in pots in the ground or in appropriately selected substrate with the use of control technologies and with the application of adequate hydration, lighting and environmental parameters inside buildings. By the use of intelligent solutions, it is possible to increase the effectiveness and efficiency of production protected from pollution coming from the external environment and from pests. An example of this is the implementation of the Pasona Urban Farm inside Pasona Group headquarters building, erected in Tokyo, Japan in 2010.

The third type of crop may be described as the industrialized production of plants in buildings in the city. This is fully automatic, highly specialized cultivation system in which the parameters of vegetation growth are controlled by means of modification to environmental parameters, lighting parameters and nutrients contained in water in which plants are rooted. Depending on the adopted technology, the types of cultivation that may be distinguished include hydroponic cultivation (in flowing water), aquaponics cultivation (in water using fish) and aeroponic cultivation (using a mixture of minerals sprayed in the root zone of plants).

The fourth type of plant cultivation in the city refers to algae (algae) farms. The cultivation and use of algae in connection with architecture have been constructed in the form of experimental realizations, such as the Bio-Intelligent Quotient (BIQ) building in Hamburg (Roedel \& Petersen, 2013) or the exhibition and prototype pavilions of EcoLogicStudio (in Milano 2015, in Braga 2015, in Aarthus 2017). Algae in the form of biomass are used as bio fuels, catalysts, agents for wastewater treatment, agents for the production of oxygen, hydrogen and as food products, dietary supplements and cosmetics. Algae are marked with a high level of ability to absorb nitrogen oxides (a dangerous component of fumes and smog). At the same time, research is conducted on the use and selection of appropriate mosses species to be applied in order to improve air quality in the city. However, the algae present a higher level of efficiency.

The conducted analysis and considerations regarding revitalization are closely connected with new ways to form the functional-spatial structure, as well as building development integrated with biologically active areas.

In case of the undertaken revitalization projects and activities, the basic issue is to properly diagnose and recognise the cultural, technical and natural values present in the degraded areas, as well as the analysis concerning the needs in relation to the metropolitan structure, the group of its users and the local community inhabiting the area. It is also necessary to determine degradation causes, which may include: excessive exploitation, social and economic changes, economic and legal conditions, political decisions, competitive investments in the neighbourhood that seem to be "sucking" life and the area users.

Conducting a multi-criteria analysis makes it possible to adjust activities to local, spatial, social and ecosystem-related conditions and needs in accordance with the forecasted progress directions. When 
determining the natural conditions, it is necessary to recognize the nature and complexity of greenery, which often spontaneously took over areas abandoned by the original users, which specialist call informal greenery. Another observable issue concerns valuing of "spontaneous greenery" that often grows under "extreme" conditions. Moreover, there occurs a matter of balancing the biologically active surface. The concept or "informal greenery" is discussed in the scientific circles (Gawryszewska \& Lepkowski, 2016). It is particularly important in relation to revitalization activities in areas and buildings covered with various plants. Conducting revitalization, it is necessary to program, combine and manage space, taking into account social participation and Nature' participation (World Charter for Nature - 1982, The Earth Charter 2000, Universal Declaration of Rights of Mother Earth - 2010, Rights of Nature Tribunal - 2017) to benefit the needs of a dynamically changing local community and a natural system sensitive to climate and environmental changes, so as to provide proper conditions for the regeneration and reconstruction of ecosystem services in the human-created space and building development. One of the issues concerning regenerative green and blue infrastructure design is the implementation of biologically active surfaces integrated with buildings and implemented in public spaces within the urban landscape.

While shaping space and designing the metropolitan functional-spatial structure, designers should take into account the contemporary concepts and technologies that advantage from the implementation of greenery in buildings and a top of them. Research is conducted on the quality and efficiency of biologically active areas, so as to optimize tasks posted by greenery and water fronts in the city. Revitalization thus, stands in close relation to the application of green and blue infrastructure in the urban space and to the natural system of the metropolis.

\section{SUMMARY}

The described research work and conducting research in the context of multithreaded revitalisation of fragments of the city, buildings and green infrastructure are the beginning of research in this field.
The literature describes examples of investments, but there is no synthesis and no indication of the need for spatial policies and revitalisation programmes. The aim of the article is to make the reader aware of the scope of activities and directions of development of the urban structure, green infrastructure and ecosystem in the city in the context of degraded areas. Transformations of buildings and areas in poor technical condition, devastated, unused, with threatening environmental parameters and ecosystem deficits. That is, areas requiring intervention for space, community and ecosystem in the city.

Selection of source material and literature was aimed at verification of research assumptions. In total, in terms of research categories, a case study of about 30 different investments in metropolises in the USA, Asia and Europe was carried out, realized after 2000.

Based on the analysis of examples of green roofs, urban farms and revitalisation assumptions, it appears that in revitalised areas it is possible to introduce the functions of a farm in green infrastructure. Analysed revitalisation programmes should include farms in the urban greenery system. Plants integrated with the building are one of the elements of contemporary shaping of revitalised areas and buildings. This is indicated by the literature and analysis of the implementation and design which constituted a research group of investments from the USA, Asia and Europe. In conclusion, an urban farm introduced as green roofs and green walls may be seen as an example of integrating greenery with buildings in the urban landscape. Implementation of plant cultivation in the city should become a part of the revitalization program in case of the modern metropolis. According to the local, natural, spatial, cultural, social, economic and infrastructural conditions, the optimal type of an urban farm should be specified (according to the indicated typology of edible plants integrated with the building development). In the revitalization program, the implementation manner and the task concerning the optimized green and blue infrastructure should also be determined. The analysis of the results of scientific research on ecosystem services (Szczepanowska, 2007; Kronenberg, 2016) and the study on the biologically active areas efficiency in the metropolis (Szulczewska, 2014) prove the hypothesis of the following 
Grochulska-Salak, M., Zinowiec-Cieplik, K. (2019). Revitalization of areas in the metropolis - an urban farm as an example of integration of greenery and buildings in the urban landscape. Acta Sci. Pol. Architectura, 18 (3), 15-24. doi: 10.22630/ASPA.2019.18.3.31

research, as well as they account for the legitimacy of the introducing urban farms in the areas under revitalisation.

\section{REFERENCES}

Bać, A. (2012). „Zielone miasta” jako szansa na zrównoważony rozwój na przykładzie Vancouver. In K. Derejski, J. Kubera, S. Lisiecki \& R. Macyra (eds.), Deklinacja odnowy miast. $Z$ dyskusji nad rewitalizacja $w$ Polsce (pp. 279-289). Poznań: Wydawnictwo Naukowe Wydziału Nauk Społecznych UAM w Poznaniu.

Białecka, B. (2014). Zrównoważona rewitalizacja terenów zdegradowanych - dobre praktyki. Katowice: Główny Instytut Górnictwa.

City of Chicago (2001). A Guide to Rooftop Gardening. From the City of Chicago. Chicago. Retrieved from: http://sites.saic.edu/greeninitiatives/greenroofs/images/ GuidetoRooftopGardening v2.pdf.

City of Toronto (2017). Green Roof Bylaw. Toronto Municipal Code. Chapter 492: Green Roofs. Toronto. Retrieved from: http://www.toronto.ca/legdocs/municode/1184_492.pdf

Cole Plakias, A. (2016). The Farm on the Roof: What Brooklyn Grange Taught Us about Entrepreneurship, Community, and Growing a Sustainable Business. New York NY: Avery Publishing Group.

Derejski, K., Kubera, J., Lisiecki, S. \& Macyra, R. (2012). Deklinacja odnowy miast. $Z$ dyskusji nad rewitalizacja w Polsce. Poznań: Wydawnictwo Naukowe Wydziału Nauk Społecznych UAM.

Gawryszewska, B. \& Łepkowski, M. (2016). Estetyka nieużytku we współczesnej architekturze krajobrazu miasta. Sztuka i Filozofia, 49, 17-31.

Gnich, T. (2015). Największa nowojorska farma na dachu - Brooklyn Grange. Retrieved from: http://urbnews. pl/najwieksza-nowojorska-farma-na-dachu-brooklyngrange/ [accessed 01.12.2018].

Hulicka, A. (2013). Idea Miasta Zielonego - stan badań i perspektywy rozwoju. In A. Zborowski (Ed.), Człowiek - Spoleczeństwo - Przestrzeń. Vol. II.I (pp. 137-147). Kraków-Myczkowce: Instytut Geografii i Gospodarki Przestrzennej i Centrum Kultury Ekumenicznej.

Kazmierczak, A. \& Carter, J. (2010). Adaptation to climate change using green and blue infrastructure. A database of case studies. Manchester: The University of Manchester.

Köhler, M. (2010). Zielone dachy i ściany a zagospodarowanie wód opadowych w mieście. Dachy Zielone, 3, 6-11.

Kowalczyk, A. (2011). Zielone dachy szansą na zrównoważony rozwój terenów zurbanizowanych. Zrównoważony Rozwój-Zastosowania, 2, 66-81.
Kronenberg, J. (2016). Usługi ekosystemów - nowe spojrzenie na wartość środowiska przyrodniczego. In A. Rzeńca (ed.), EkoMiasto\#Środowisko. Zrównoważony, inteligentny i partycypacyjny rozwój miast (pp. 63-88). Łodź: Wydawnictwo Uniwersytetu Łódzkiego.

Kwiecińska, K. \& Szałata, Ł. (2012). Zielone dachy elementem zielonych miast. In M. Kosmala (ed.), Zieleń a klimat społeczny miasta. (pp. 197-209). Toruń: Polskie Zrzeszenie Inżynierów i Techników Sanitarnych Oddział Toruń.

Loi no 2016-1087 du 8 août 2016 pour la reconquête de la biodiversité, de la nature et des paysages. JORF no 0184 du 8 août 2016 [Law No 2016-1087 on the Recovery of Biodiversity, Nature and Landscapes of 8 August 2016]. JORF no 0184 of 8 August 2016.

Millennium Ecosystem Assessment [MEA] (2005). Ecosystems and Human Well-being: Synthesis.Washington, DC: Island Press.

New York City Council (2018). Green Roofs act for New York City. Requiring that the roofs of certain buildings be covered in green roofs or solar photovoltaic electricity generating systems. New York NY.

Roedel, Ch. \& Petersen, J-P. (2013). Smart Material House $B I Q$. Hamburg: IBA Hamburg.

Specht, K., Siebert, R., Hartmann, I., Freisinger, U. B., Sawicka, M., Werner, A., Thomaier, S., Henckel, D., Walk, H. \& Dierich, A. (2013). Urban agriculture of the future: an overview of sustainability aspects of food production in and on buildings. Agriculture and Human Values, 31 (1), 33-51.

Szajda-Birnfeld, E., Pływaczyk, A. \& Skarżyński, D. (2013). Zielone dachy. Zrównoważona gospodarka wodna na terenach zurbanizowanych. Wrocław: Wydawnictwo: Uniwersytet Przyrodniczy we Wrocławiu.

Szczepanowska, H. B. (2007). Wycena wartości drzew na terenach zurbanizowanych. Warszawa: Instytut Gospodarki Przestrzennej i Mieszkalnictwa.

Szulczewska, B., Giedych, R., Borowski, J., Kuchcik, M., Sikorski, P., Mazurkiewicz A. \& Stańczyk, T. (2014). How much green is needed for a vital neighbourhood? In search for empirical evidence. Land Use Policy, 38, 330-345.

Tokarska, A. \& Osyczka, D. (2011). Zielone dachy jako odpowiedź na intensywną zabudowę miast. Zeszyty $\mathrm{Na}$ ukowe. Inżynieria Środowiska, 143 (23), 6-18.

Ustawa z dnia 9 października 2015 r. o rewitalizacji. Dz.U. 2015, poz. 1777 [Act on revitalization of 9 October 2015. Journal of Laws 2015, item 1777]. 


\section{REWITALIZACJA OBSZARÓW METROPOLII - MIEJSKA FARMA JAKO PRZYKŁAD INTEGRACJI ZIELENI I BUDYNKÓW W KRAJOBRAZIE MIEJSKIM}

\section{STRESZCZENIE}

Nowoczesne metropolie wprowadzają programy rewitalizacji, które umożliwiają bardziej racjonalne i zrównoważone wykorzystanie zasobów ekosystemowych. W artykule przeanalizowano działania rewitalizacyjne rozumiane jako proces rozwoju związany z wdrażaniem nowatorskich rozwiązań pozwalających na integrację budynków z naturą. Badania koncentrowały się także na projektach i przeprowadzonych wdrożeniach miejskich upraw, które zarówno stanowią przykłady inwestycji publicznych o charakterze prospołecznym, jak i tworzą miejsca o rosnącym ogrodniczym znaczeniu, mające w przyszłości zaspokoić potrzeby żywieniowe lokalnej społeczności. W pracy przedstawiono badania nad interdyscyplinarną dyskusją na temat rewitalizacji miast poprzez realizację miejskich gospodarstw w nowoczesnych metropoliach XXI wieku. Traktowanie budynków jako biotopu może zwiększyć powierzchnie biologicznie czynne. Szukając możliwości zwiększenia powierzchni produkcji rolnej w miastach, okazuje się, że dachy i elewacje mają duży potencjał. W artykule przedstawiono typologię upraw miejskich, które pojawiły się na powierzchniach architektonicznych w ostatnich 20 latach, w celu pokazania możliwości wykorzystania ich jako ważnego czynnika i części składowej rewitalizacji miasta.

Słowa kluczowe: rewitalizacja, metropolia, rewitalizacja gruntów, uprawy miejskie, farmy miejskie, zieleń zintegrowana $\mathrm{z}$ budynkami 